Indian Journal of Science and Technology

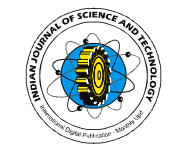

Vol.2 No. 10 (Oct 2009)

ISSN: 0974- 6846

\title{
Foliar epidermal morphology of some Nigerian species of Senna (Caesalpiniaceae)
}

\author{
O.T. Ogundipe, A. B. Kadiri and O. H. Adekanmbi \\ Department of Botany and Microbiology, University of Lagos, Lagos, Nigeria. \\ abkadiri2001@yahoo.com
}

\begin{abstract}
A comparative foliar epidermal and petiole anatomical morphology of six commonly used pharmacodynamic species of Senna in Nigeria was investigated with a view to elucidating their taxonomic significance and present complementary data which would aid the recognition of the species. The cell shape may be polygonal and irregular on both surfaces and either polygonal or irregular on any of the two surfaces of the leaf. Anticlinal wall is either straight or undulate and curved. Usually, the epidermal cell size is more on the adaxial surface and the leaf is either amphistomatic or hypostomatic. Trichomes are usually slender acicular to conical and glandular or non-glandular. The vascular system of the petiole is arranged in a spaced arc. Based on this an indented dichotomous key is presented to distinguish the species.
\end{abstract}

Keywords: Senna, foliar, morphology, herbal, Nigeria

\section{Introduction}

The genus Senna syn. Cassia Linn. belongs to the family Caesalpiniaceae. It is commonly found in the tropical and sub-tropical regions of the world comprising trees, shrubs, vines and herbs with numerous representatives growing in the South American rainforest where the species spread out to the tropical Africa and other tropical regions of the world. There are about 600 species in the world out of which 25 species were recorded in West Africa. (Hutchinson \& Dalziel, 1958; Hutchinson, 1964). Most of the species are endemic, introduced, commonly cultivated or probably naturalized (Hill, 1952). The six popular medicinally useful species namely: Senna occidentalis (Linn.) Link, Senna hirsuta (Linn.) Irwin \& Barneby, Senna alata (Linn.) Roxb., Senna podocarpa (Guill. \& Perr.) Lock, Senna sophera (Linn.) Roxb. and Senna nodosa Ham. were studied in order to provide a complementary data obtained from foliar epidermal and anatomical features so as to aid easy recognition of the species for pharmacognostic researches. The use of natural medicine is a popular practice in Nigeria. Many species of Senna have been used medicinally, they have a rich history in natural medicine and they have been known since the 9th or 10th century as purgative and laxatives. Seeds of $S$. occidentalis are substituted for coffee. Generally, Senna bark and oil extract are used for flavouring purposes and in soaps, candy and perfumery (Hill, 1952). The leaf is the ubiquitously used part because of its utilization and therapeutic values. But generally, the leaf, flower, root and seed are used in herbal medicine all over the world (Dennis, 1988). Their actions include, analgesic, antibacterial, antifugal, antihepatotoxic, anti inflammatory, antiseptic, antiparasitic, diaphoretic emmenagogue, laxative, vermifuge, purgative, stomachic, febrifuge and other reproductive problems arbortifacient (Burkill, 1995; Dennis, 1988).

$S$. occidentalis has been reported to accumulate oxymethyl anthraquinone alkaloids, in the leaf and tannins, toxalbumin, chrysopanic acid and emodine in the seeds. Economically, the roasted seeds can be used to substitute coffee, which is well used throughout the range of the plant's dispersal. The plant is potent for curing herpes, chest pains and elephantiasis (Burkill, 1995).

In $S$. alata every part of the plant is medicinally useful. The plant can be used as insect repellent, for regulating menstrual flow, treating dermal-related infections, gonorrhoea, jaundice, vermifuge and pains. The plant contains significant amount of chrysophanic acid which is known to be effective on skin pathogens, anthroquinones , saponins tyramine and hydrocyanic acid (Burkill, 1995).

S. podocarpa contains anthraquinones and a beautification dye. It is used for treating skin diseases, as strong purgative and also given to pregnant women to ease delivery (Burkill, 1995).

The uses of $S$. sophera are vicariously interchangeable with those of $S$. occidentalis. Although, there is medicinal account reported on $S$. nodosa, but it is selected for its aesthetic relevance.

The present study was undertaken with a view to contributing more anatomical data that would aid the recognition of these drug plants in order to eliminate adulteration since herb sellers are the main sources from whom the plants can be purchased in Nigeria for pharmacognostic researches.

\section{Materials and methods}

The leaf and petiole were used for the study. Fresh specimens of the species were either obtained from the botanic garden of the University of Lagos or collected elsewhere across the south-western Nigerian where the species are well distributed and then authenticated at the herbarium of the University (LUH). What does LUH represent?
Research article

CIndian Society for Education and Environment (iSee)
"Folio-anatomical identity of Senna spp." http://www.indjst.org
Ogundipe et al. Indian J.Sci.Technol. 
Indian Journal of Science and Technology

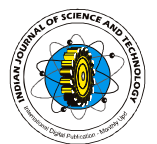

Table 1. A comparative foliar epidermal and petiole anatomical morphology of six commonly used pharmaco-dynamic species of

Senna in Nigeria

\begin{tabular}{|c|c|c|c|c|c|c|c|c|c|c|c|}
\hline $\begin{array}{l}\text { Species } \\
\text { Ad./Ab. } \\
\text { surfaces }\end{array}$ & $\begin{array}{l}\text { Cell } \\
\text { shape }\end{array}$ & $\begin{array}{l}\text { Wall } \\
\text { pattern }\end{array}$ & $\begin{array}{l}\text { Stomatal } \\
\text { type }\end{array}$ & Trichomes & Cell No. & $\begin{array}{l}\text { Cell length } \\
(\mu \mathrm{m})\end{array}$ & $\begin{array}{l}\text { Cell width } \\
(\mu \mathrm{m})\end{array}$ & $\begin{array}{l}\text { Stomatal } \\
\text { No. }\end{array}$ & $\begin{array}{c}\text { Stomatal } \\
\text { length } \\
(\mu \mathrm{m})\end{array}$ & $\begin{array}{l}\text { Stomatal } \\
\text { width }(\mu \mathrm{m})\end{array}$ & $\begin{array}{l}\text { Stomatal } \\
\text { index }\end{array}$ \\
\hline \multirow{2}{*}{ S.occidentalis } & $\mathrm{P}, \mathrm{I}$ & $\mathrm{S}, \mathrm{U}$ & PA,AN & - & 29 & $31.5-49.0$ & $14.5-42.5$ & 10 & $10.6-19.0$ & $10.2-10.4$ & $25 \%$ \\
\hline & $P, I$ & $\mathrm{~S}, \mathrm{C}$ & $\mathrm{PA}, \mathrm{AN}$ & + & 23 & $31.0-50.0$ & $12.5-38.5$ & 22 & $10.5-11.5$ & $10.2-10.3$ & $49 \%$ \\
\hline \multirow{2}{*}{ S. hirsuta } & $\mathrm{P}, \mathrm{I}$ & $\mathrm{S}, \mathrm{U}$ & $\mathrm{PA}, \mathrm{AN}$ & + & 39 & $18.5-48.0$ & $12.0-37.5$ & 6 & $10.8-12.0$ & $10.1-10.3$ & $13 \%$ \\
\hline & $\mathrm{P}, \mathrm{I}$ & $\mathrm{S}, \mathrm{C}$ & PA,AN & + & 30 & $28.5-50.0$ & $15.0-31.5$ & 21 & $10.8-11.5$ & 10.1-10.3 & $41 \%$ \\
\hline \multirow{2}{*}{ S. alata } & $\mathrm{P}$ & $\mathrm{S}$ & PA & + & 73 & 10.9-13.5 & $11.0-12.8$ & 17 & 10.8-11.5 & 10.4-11.2 & $18.8 \%$ \\
\hline & I & $\mathrm{S}, \mathrm{C}$ & $\mathrm{PA}$ & + & 50 & $11.5-14.0$ & $11.0-12.3$ & 35 & $11.3-11.7$ & 10.9-11.2 & $41.2 \%$ \\
\hline \multirow{2}{*}{$\begin{array}{l}\text { S. } \\
\text { podocarpa }\end{array}$} & 1 & $\mathrm{U}$ & $\mathrm{PA}$ & + & 71 & $12.0-4.5$ & $11.3-14.0$ & 4 & $11.6-2.0$ & $11.0-1.3$ & $5.33 \%$ \\
\hline & 1 & $\mathrm{C}$ & $\mathrm{PA}$ & + & 68 & $11.6-3.5$ & 11.2-12.2 & 20 & 11.5- 1.8 & $11.1-1.5$ & $22.7 \%$ \\
\hline \multirow{2}{*}{ S. sophera } & I & C & $\mathrm{PA}$ & - & 47 & $10.3-1.2$ & $10.1-10.7$ & 14 & $10.3-0.5$ & $9.8-10.1$ & $23 \%$ \\
\hline & 1 & $\mathrm{C}$ & PA & - & 43 & $10.1-1.2$ & $10.1-10.7$ & 30 & 10.2- 0.6 & $9.5-10.2$ & $41.1 \%$ \\
\hline \multirow{2}{*}{ S. nodosa } & $P$ & $\mathrm{~S}$ & - & + & 109 & 10.3- 0.9 & $10.0-10.5$ & - & - & - & - \\
\hline & $\mathrm{P}$ & $\mathrm{S}$ & AN & + & 85 & 10.3- 0.5 & $10.0-10.3$ & 58 & $9.8-10.5$ & $9.5-10.1$ & $40.5 \%$ \\
\hline
\end{tabular}

$P=$ polygonal, I=irregular, $S=$ straight, $C=$ curved, $U=$ =undulate, $P A=$ paracytic, $A N=$ anomocytic, Cell No. \& Stomatal No.in means.

Plate 1: Photomicrographs showing epidermal characteristics of $S$. occidentalis $(A, B) ; S$. hirsuta $(C, D)$ and $S$. podocarpa $(E, F)$. The epidermides show straight to curved and undulate anticlinal wall, irregular and polygonal cell shape and paracytic to anomocytic stomata. Scale bar is $25 \mu \mathrm{m}$
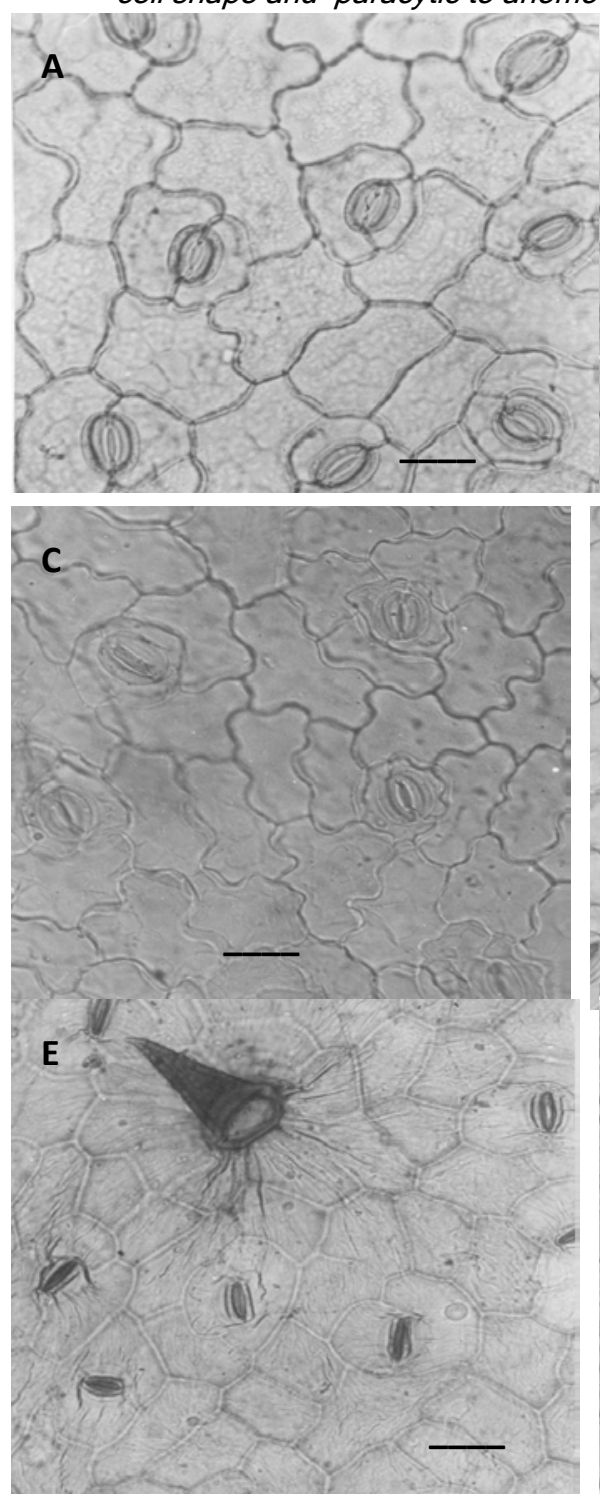

Research article

CIndian Society for Education and Environment (iSee)
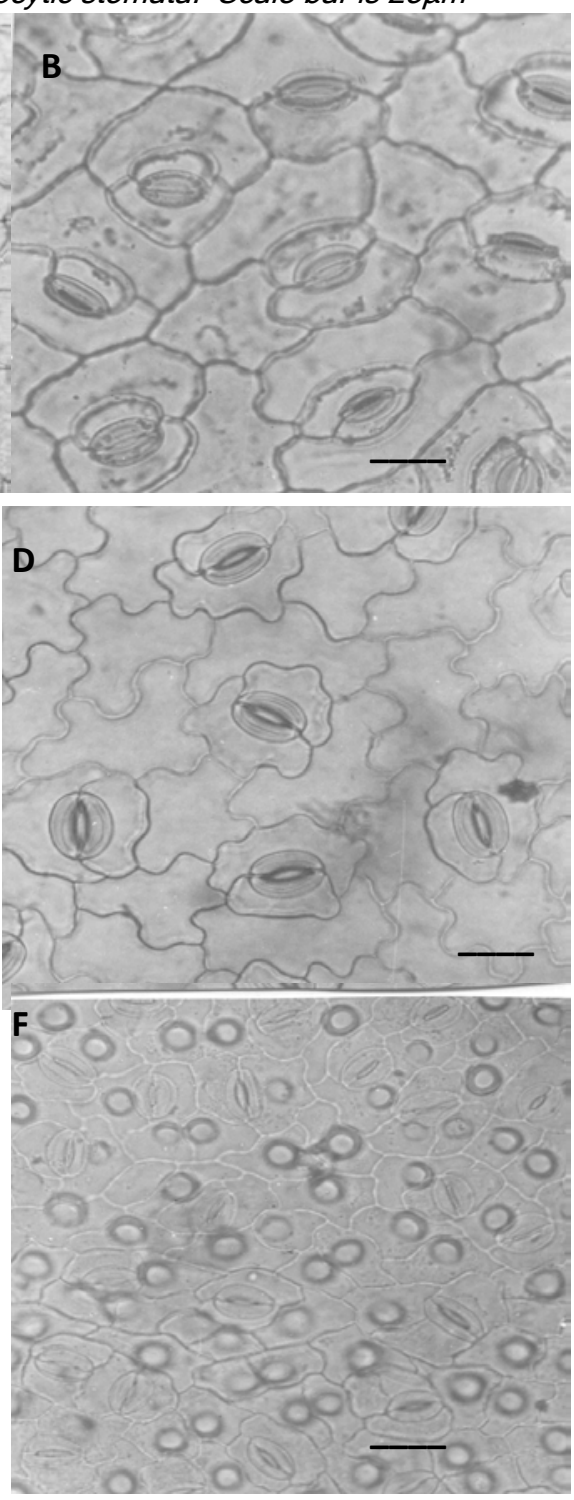

"Folio-anatomical identity of Senna spp." http://www.indjst.org
Epidermal preparations were obtained by macerating herbarium material with either Jeffrey's or sodium hypochlorite solution. (Stace, 1965; Ogundipe, 1992; Ogundipe, 1999; Kotresha \& Seetharam, 2000; Ogundipe \& Wujek, 2004). The cleaned epidermides were stained using $3 \%$ aqueous solution of Safranin $O$, washed in 2 to 3 changes of $50 \%$ ethanol to remove excess stain and mounted in glycerine.

Fresh materials and dried materials of petiole after boiling in water for tissue revival were subsequently fixed in Formalin-Acetic Alcohol (FAA) and then embedded in wax for sectioning. Transverse sections were either cut with a razor blade using free hand or on a sliding microtome and were stained with few drops of phloroglucinol and Hydrochloric acid. Some were stained in 3\% aqueous solution of Safranin $\mathrm{O}$ and counter stained in Alcian blue. They were then mounted in glycerine and specimens were observed at $x 40$ objective magnification.

Images were computerized digitally with a Motic image plus version $2.0 \mathrm{ml}$ mounted on Zeiss Light Microscope. Stomatal index was calculated using the method of Stace (1965).

\section{Observation \\ Epidermal cells}

The cell shape is usually polygonal and irregular on the adaxial and abaxial surfaces respectively in $S$. occidentalis, $S$. hirsuta, and $S$. alata but it is polygonal on both surfaces in $S$. nodosa and usually irregular in $S$. podocarpa and $S$. sophera (Table 1, Plates 1, 2). The anticlinal wall patterns vary from straight and undulate or straight and curved in $S$. occidentalis, $S$.

Ogundipe et al. Indian J.Sci.Technol. 
hirsuta, and $S$. alata to entirely straight in $S$. nodosa, curved in $S$. sophera or undulate / curved in S. podocarpa (Table 1, Plates 1, 2). Epidermal cell size is more on the adaxial surface than abaxial surface in all the species (Table 1). Mean cell size varies from to $5.0 \times 3.0 \mu \mathrm{m}$ in $S$. nodosa on the abaxial surface to $40.8 \times 26.6 \mu \mathrm{m}$ in S.occidentalis on the adaxial surface (Table1).

\section{Stomatal apparatus}

The leaf is amphistomatic in all the species except $S$. nodosa, which is the only tree species that is hypostomatic. Anomocytic and paracytic stomata are usual in all the species (Table 1). In all the amphistomatic

Plate 2. Photomicrographs showing epidermal characteristics of S.alata $(A, B)$; $S$. sophera $(C, D)$ and $S$. nodosa $(E, F)$. The epidermides show straight to curved and undulate anticlinal wall, irregular and polygonal cell shape and paracytic to anomocytic stomata. Trichomes may be straight to curved, conical and glandular or non-glandular types. Scale bar is $25 \mu \mathrm{m}$
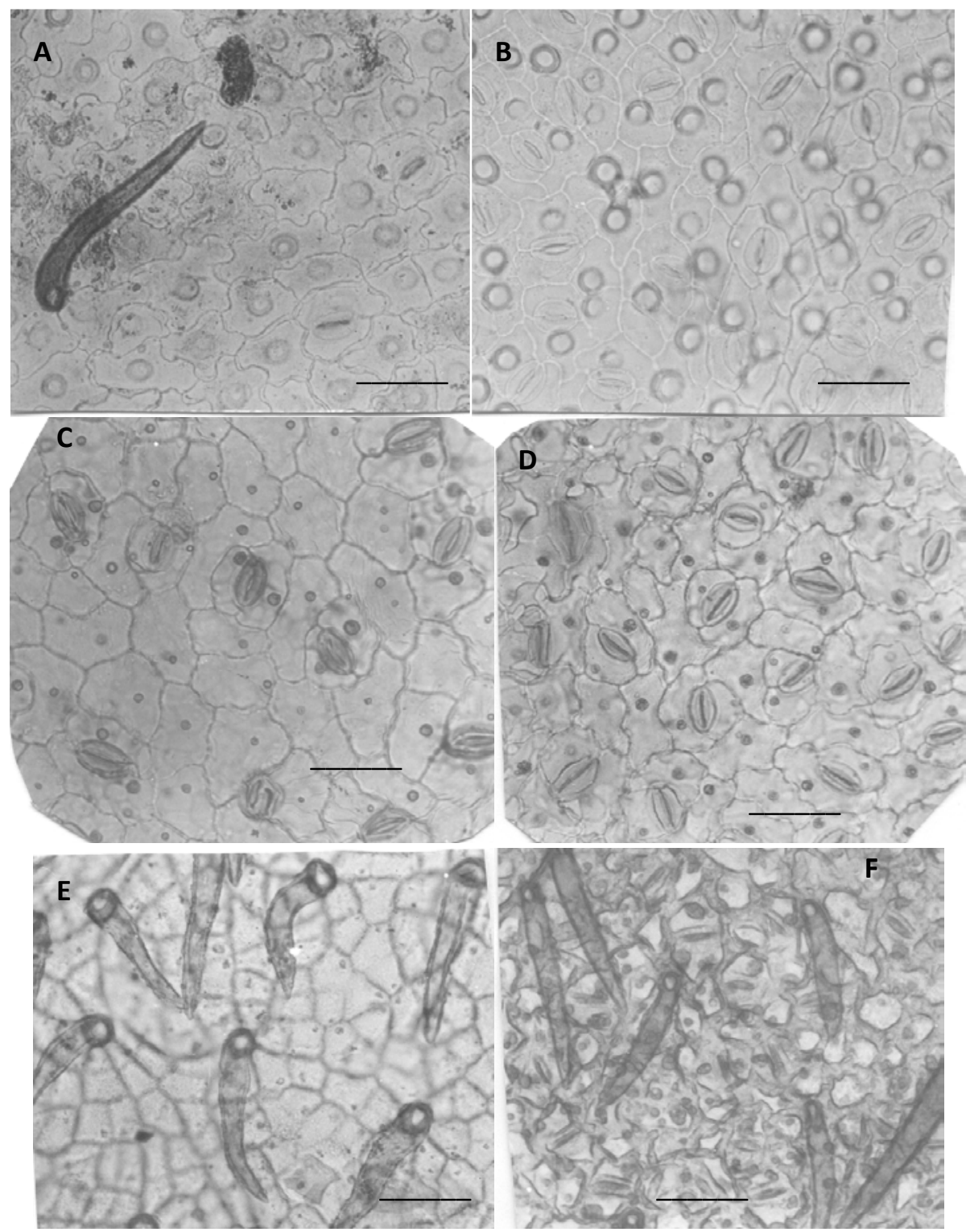

species, stomatal frequency is more on the abaxial

Research article

(c)Indian Society for Education and Environment (iSee)
"Folio-anatomical identity of Senna spp." http://www.indjst.org
Vol.2 No. 10 (Oct 2009)

ISSN: 0974- 6846 surface than adaxial surface. Stomatal size varies from $1.0 \mu \mathrm{m}$ in $\mathrm{S}$. nodosa to $18.2 \times 11.9 \mu \mathrm{m}$ in $\mathcal{S}$. exist within the range of $5.3 \%$ in S. podocarpa to $49 \%$ in occidentalis

Trichomes are restricted to the abaxial surface in $S$. occidentalis or present on both surfaces of the leaf in other species except $S$. sophera that is glabrous (Table 1). Long unicellular, acicular to conical trichomes which may be glandular or non-glandular and usually with surrounding base cells were recorded in all the species except S. sophera (Plate 2C, D). Maximum trichome length varies from $25.0 \mu \mathrm{m}$ to $42.5 \mu \mathrm{m}$ in $S$. nodosa and $S$. podocarpa, respectively on the abaxial surface (Table 1).

Petiole

The outline is imperfectly oval. The perivascular bundles vary from oval shape to polygonal and the number of cell layers in parenchyma is numerous whereas it varies from 1 to about 5 in other ground tissues. The vascular bundles are either wholly or partially separated into plates (Plate 4).

The uniformity in petiole characteristics is a pointer to the close affinity existing among these species and naturalness of the genus.

\section{Discussion}

Taxonomic relevance of vegetative anatomy in taxa delimitation, recognition and establishment of affinities is well reported (Tomblinson, 1961; Stace, 1965; Kotresha \& Seetharam, 1995, 2000). The present investigation has revealed the variation patterns in the epidermal morphology of the six species of the genus. The cell shape may be polygonal and irregular on both surfaces or polygonal and irregular on both surfaces. Anticlinal wall is either straight or undulate and curved and usually, the epidermal cell size is more on the adaxial surface. The leaf is amphistomatic in all the species except $S$. nodosa which is the only tree species that is hypostomatic; this however is in consonance with the reports of Metcalfe and Chalk, 1950, 1979 and Kotresha and Seetharam, 2000 but against the work of Boodle and Fritsch, 1908. Anomocytic and paracytic stomatal types are usual in all the species, although four types viz paracytic, tetracytic, anisocytic and anomocytic have 
been recorded in the genus. Trichomes may occur on both surfaces or restricted to either side or totally absent especially in $S$. sophera. The glabrous leaf distinguishes $S$. sophera from $S$. occidentalis, these species are often confused, they are exo-morphologically identical except in their terminal leaflets and fruit size (Hutchinson \& Dalziel, 1958). $S$. nodosa has the smallest stomatal size in all the species but $S$. sophera, $S$. nodosa,$S$. hirsuta and $S$. alata have uniform stomatal index on the abaxial surface, this therefore indicates that they are very close. The vasculature in the petiole is arranged in a closed arc and all members of the ground tissue are present.

Plate 3: Photomicrographs showing epidermal characteristics of S. hirsuta $(A, B) ; S$. occidentalis $(C, E) ; S$. sophera $(D) ; S$. podocarpa $(F)$ and $S$. alata $(G)$. Trichomes are long acicular- conical which may be glandular or non-glandular. Note globose glandular trichomes in $C$. hirsuta $(A, B, E)$ and $C$. occidentalis, and multicellular trichome scar in $C$. hirsuta $(B)$. Scale bar is $75 \mu \mathrm{m}$.

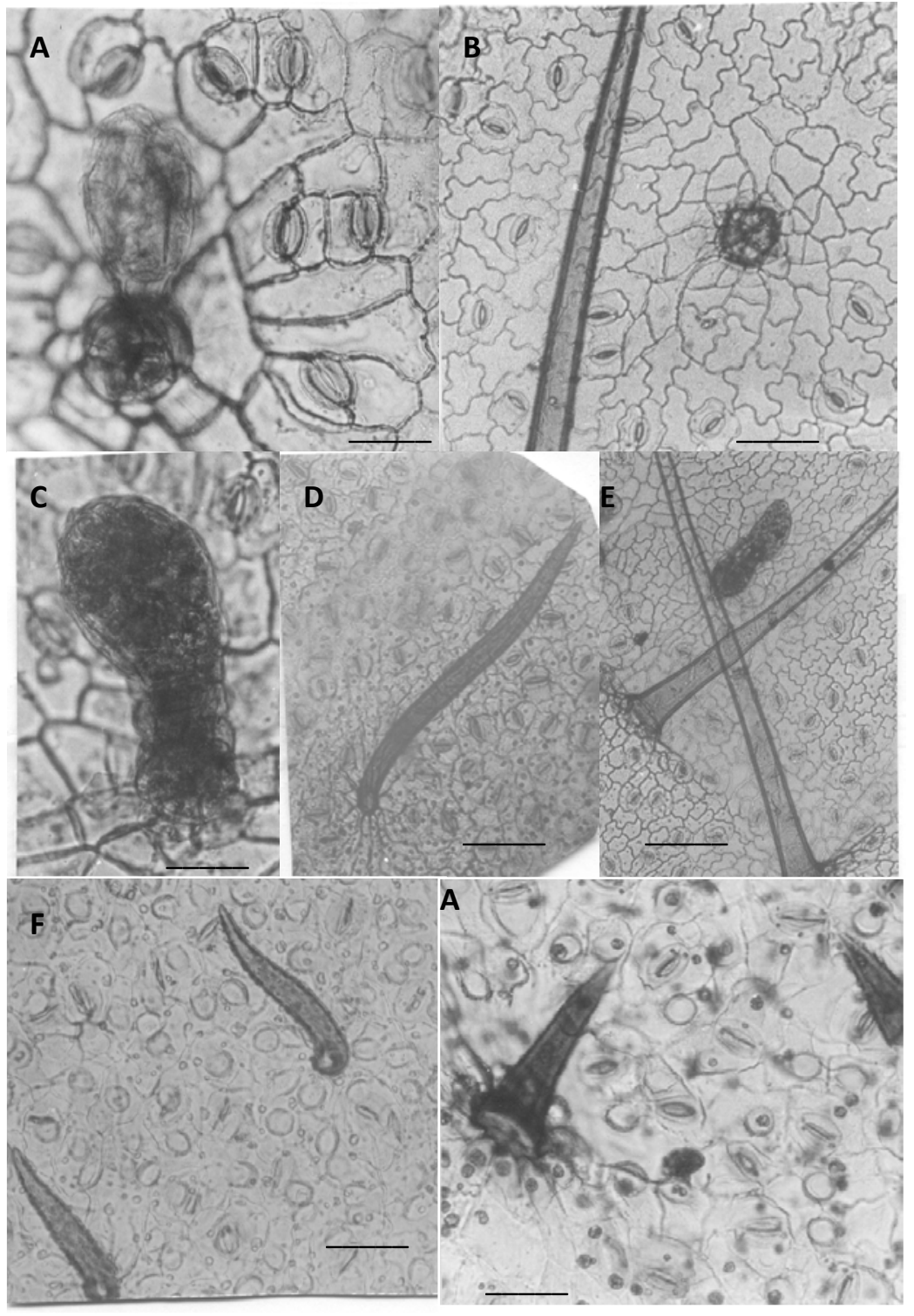

Vol.2 No. 10 (Oct 2009)

ISSN: 0974- 6846

Based on the most reliable features that are reported in the present study, an indented dichotomous key is thus presented to delimit the six species which were investigated in the genus.

An artificial indented dichotomous key for separating the six species investigated in the Nigerian Senna.

1. Leaf amphistomatic, stomatal type only anomocytic.

2. Leaf entirely pubescent, cell wall pattern usually straight. nodosa

2. Leaf either glabrous or pubescent, cell wall pattern straight, curved or undulate.

1. Leaf hypostomatic. Stomatal types anomocytic and paracytic or paracytic only.(Check this area in red for correct numbering)

3. Stomatal index less then $40 \%$ on the abaxial surface, cell shape usually irregular on both surfaces of the leaf. podocarpa

3. Stomatal index not less than $40 \%$ on the abaxial surface, cell shape polygonal or irregular on either surface of the leaf.

4. Leaf entirely glabrous, stomatal number twice more on the abaxial than adaxial...............sophera

4. Leaf surface entirely pubescent, stomatal number up to five times more on the abaxial than adaxial surface.

5. Cell and stomatal number up to 50 and 35 respectively on the abaxial surface.......alata

5. Cell and stomatal number not more then 30 on the abaxial surface.

6. Cell number not up to 30 on the adaxial and abaxial surfaces........occidentalis

6. Cell number up to 30 on the adaxial and abaxial surfaces. .......hirsuta

\section{References}

1. Boodle L A and Fritsch FE (1908) Solereder's Systematic Anatomy of the Dicotyledons. Revised by Scott DH. Vol. I \& II, Clarendon Press, Oxford, U.K.

2. Burkill HM (1994) The Useful Plants of West Tropical Africa (2 $^{\text {nd }}$ Edition) Vol. 2. Royal Botanic Garden, Kew. pp: 21-25.

3. Dennis PA (1988) Herbal Medicine among the Miskito of Eastern Nicaragua. Economic Botany. 42 (1), 16-28.

4. Hill FA (1952) Economic Botany. McGraw Hill Books Company, New York. pp: 560.

5. Hutchinson J (1964) The Genera of Flowering Plants (Angiospermae). Oxford Press, London. pp: 489.

6. Hutchinson $\mathrm{J}$ and Dalziel JM (1958) Flora of west tropical Africa v.1 p.2. Crown agents for Overseas Governments and Administrations, London. pp: 828.

7. Kotresha K and Seetharam YN (2000) Epidermal micromorphology of some Cassia L. (Caesalpiniaceae). Phytomorphology. 50
Research article

CIndian Society for Education and Environment (iSee)
"Folio-anatomical identity of Senna spp." http://www.indjst.org
Ogundipe et al. Indian J.Sci.Technol. 
(3\&4), 229- 237.

8. Kotresha K and Seetharam YN (1995) Epidermal Studies in some species of Bauhinia $L$. (Caesalpinioideae). Phytomorphotogy. 45 (1\&2), 127137.

9. Metcalfe CR and Chalk L (1950) Anatomy of the Dicotyledons. Oxford Univ. Press, Oxford. pp: 724.

10. Metcalfe CR and Chalk L (1979) Anatomy of the Dicotyledons $\left(2^{\text {nd }}\right.$ ed.). Vol. 1. Oxford Univ. Press, Oxford. pp: 276.

11. Ogundipe OT and Wujek DE (2004) Foliar anatomy on twelve genera of Bignoniaceae (Lamiaceae). Acta Bot. Hung. 46, 290- 312.

12. Ogundipe OT (1992) Leaf Epidermal studies in the genus Datura Linn. (Solanaceae) Phytomorphology. 42, 209-217.

Plate 4. Photomicrographs showing petioles in transverse sections. $S$. occidentalis $(A) ; S$. hirsuta $(B) ;$ S. alata (C);S. podocarpa (D); $S$. sophera (E) and $S$. nodosa $(F)$. Note the pubescent surface of $C$. hirsuta (B), spacedcollateral vasculature and imperfectly oval outline. Scale bar is $50 \mu \mathrm{m}$.

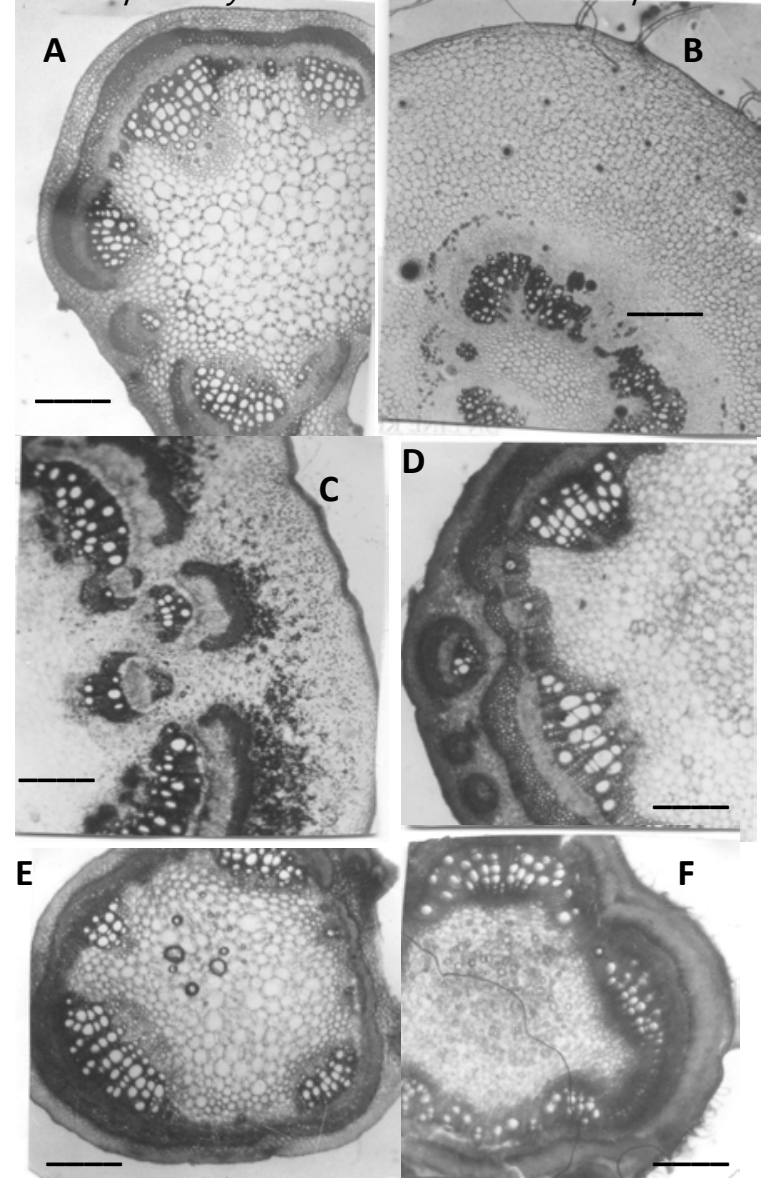

13. Ogundipe OT and Akinrinlade OO (1999) Epidermal micromorphology of some species of Albizzia Durazz (Mimosaceae). Phytomorphology. 48, 217-323.

14. Stace CA (1965) Cuticular studies as an aid to plant taxonomy. Bull. Br. Mus. Nat. Hist. 4, 1-78.
15. Tomblinson PB (1961) Anatomical approach to the classification of the Musaceae. Bot. J. Linn. Soc. 55, 779-809.
"Folio-anatomical identity of Senna spp." http://www.indjst.org
Ogundipe et al. Indian J.Sci.Technol. 